\title{
The Influence of Christian Religious Education in Family and Parenting Styles on Adolescent Character Formation
}

\author{
Ester, ${ }^{1 *}$ Wahju Asjarjo Rini, ${ }^{2}$ Yoel Triyanto, ${ }^{3}$ Mikha Agus Widiyanto, ${ }^{4}$ Andreas Fernando ${ }^{5}$ \\ 1,2,3,5 STT Ekumene Jakarta, Jakarta, Indonesia \\ ${ }^{4}$ Sekolah Tinggi Agama Kristen Samarinda, Kalimantan Timur, Indonesia \\ *email: esterwidiyanto1986@gmail.com
}

\begin{abstract}
This study aimed to test and prove through data collection that the formation of the character of Christ in adolescents is influenced by the implementation of Christian religious education in the family and parenting patterns. The research method used in this research was the survey method - correlational. Based on the data analysis, the results showed that: 1) Christian religious education in the family had a significant effect on the formation of the character of Christ in adolescents. 2) Parenting patterns have a significant effect on the formation of Christ's character in adolescents. 3) Christian religious education in the family and parenting patterns together have a significant effect on the formation of the character of Christ. Thus, efforts to form the character of Christ in adolescents can be done by increasing the intensity of the implementation of Christian religious education in the family and increasing the right parenting pattern.
\end{abstract}

Key Words: Family's Christian religious education, parenting patterns, formation of Christ's character

Article History:

Submitted: Nov. 09, 2021

Revised: Jan. 22, 2022

Published: Jan. 29, 2022

This is an open access article under the CC BY-SA license (c)

\section{INTRODUCTION}

Adolescence is a transition period in the development stage between childhood and adulthood. This stage involves biological, cognitive, and socio-emotional changes (Bharathi \& Sreedevi, 2016). In this transition period, adolescents are faced with various problems that are very risky in their self-susceptibility and affect their future. During the search for identity, adolescents become vulnerable if they do not have a solid foundation in character formation. The role of the family becomes central in the formation of a teenager's character. The family is the first institution through the role of parents in providing guidance, guidance, and even discipline to form teenagers with good character (Justian, Widiyanto, \& Fernando, 2020).

Adolescents in this transitional period become very vulnerable in their daily lives and are easily influenced by negative things. At the stage of adolescent development, the influence of peers is very influential, while the influence of parents begins to weaken (Putro, 2017). In meeting the needs of socializing and searching for self-identity, adolescents are more easily influenced by their environmental conditions. The search for identity makes most teenagers follow the behavior of their environment so that they can be accepted in the group (Bharathi \& Sreedevi, 2016). This can make it easy for teenagers to fall into relationships in a bad environment when they cannot choose good peers. According to Darmawan and Wardhaningsih (2020), the environment is the factor with the greatest risk in adolescent development. Meanwhile, according to Gunarsa (2017), the current condition is worrying for teenagers in their development. Suhesty, Setiaji, Amalia, and Wibisono (2019) stated that juvenile delinquency in East Kalimantan Province ranks third nationally. Kutai Kartanegara is one of the districts in East Kalimantan, which is the place or object of this research. Juvenile delinquency, 
especially in Kutai Kartanegara Regency, must be a concern that needs to be studied and carried out coaching in overcoming it. This delinquency is due because good character is not yet strong formed which must be a concern for the church through the role of Christian religious education.

Delinquency among teenagers is caused by the weak foundation of spiritual values they have (Ariyanto, Mahmud, \& Wijayanti, 2012). Weak spirituality makes the character of teenagers less good, so they are easily influenced by bad companions. 1 Corinthians 15:33 states that “...evil communications corrupt good manners." The character of Christ in a teenager is the key for him not to be easily influenced by his companion. The strong character of Christ made him have a strong determination to live rightly and follow the will of Christ. To provide a foundation for the formation of adolescent character, a significant parental role is needed, through Christian religious education in the family (Ariyanto et al., 2012).

Even though the influence of parents is weakening and adolescents are giving more space to their peers, it does not mean that parents no longer have a significant role. The formation of the foundation since childhood is very decisive in adolescence. Parents who carry out the task of Christian religious education by instilling the values of Christian faith in children from an early age are very influential on the subsequent development of children, especially during adolescence. The results of research by Butler-Barnes, Martin, \& Boyd (2017), Darmawan and Wardhaningsih (2020) show that spirituality affects adolescent behavior. Socialization of parental spirituality to their children has a positive impact on adolescent behavior. Through Christian religious education in the family carried out by parents, children were educated, guided, and guided to grow in spirituality of faith and belief, so that adolescents were able to display the behavior of becoming like Christ (Harianto GP, 2012). Parents as teachers determined the formation of their teenage children to become individuals as Christ wants them to be.
The behavior of parents is a reflection of parenting style in providing guidance, discipline, and protection to their children and also affects the formation of the character of Christ in adolescents (Riati, 2016). Parenting conducted by parents greatly affected the relationship that is built with children. When parents were considered authoritarian, children are only passive and must follow the wishes of their parents, it will have an impact on the child's psychological state. Where children can become less confident, timid, and even rebellious children who are not able to control themselves well. The style of parenting for adolescents who did not allow themselves to express their desires and opinions and not provide freedom could make them look for figures outside rather their parents who are considered appropriate in the search for selfidentity, especially peers, so they will be very vulnerable to their development. Teenagers become easily provoked into bad behavior.

The formation of adolescent character cannot be separated from parenting. The result of Riati's (2016) research shows that the authoritarian parenting style has an impact on the behavior of children who make themselves obedient in front of their parents but behind them become rebellious, irritable, and critical, passive tendencies and loss of self-confidence. Being rebellious and irritable shows a negative character as a result of improper parenting. Meanwhile, children who are raised in an authoritative or democratic style show honest, independent, disciplined behavior and are easy to control emotions well. It means showing good character.

Parenting by parents greatly influences adolescent behavior. The role of religious education is very large in the formation of adolescent character, which must be done from an early age. Inappropriate parenting would affect juvenile delinquencies (Rahman, 2016). Parents play a very important role in shaping the character of Christ in adolescents. Through proper parenting, where parents perform their roles properly by providing guided freedom for children, teenagers will grow in good personalities. 
Parents in their upbringing pattern provide examples in spiritual values that will make children have a good foundation of faith and character, so that in their development during adolescence they can show the character of Christ in themselves.

The research problem is formulated: First, is there an influence of Christian Religion Education in the family on the formation of adolescent character? Second, does parenting have a significant influence on the formation of adolescent character? Third, do Christian Religion Education in the family and parenting patterns of parents together have a significant influence on the formation of adolescent character? The purpose of this study was to test and prove through data collection: First, the influence of Christian Religion Education in the family on the formation of adolescent character. Second, the influence of parenting style on the formation of adolescent character. Third, the influence of Christian Religion Education in the family and parenting style together on the formation of adolescent character.

\section{METHOD}

The method in this research is surveycorrelation. The subjects in this study were teenagers who actively worshiped at the Gereja Kemah Injil Indonesia (GKII) Sector 1, Kutai Kartanegara Regency, East Kalimantan, which consisted of 32 churches consisting of 11 churches as Community Development Posts and as many as 21 independent churches with a total number of teenagers of approximately 337 people between the ages of 11 and 16. The sample of this study was 101 people, selected from the population using multistage random sampling technique (Widiyanto, 2014).

The data collection technique used in this study was a questionnaire with a behavioral scale. The answer choices in this measurement scale with five answer choices in the statement, both positive and negative statements which include: Very Appropriate (SS), Appropriate (S), Sometimes Appropriate (KS), Not Appropriate (TS) and Never Appropriate (TPS).
In developing this research instrument, validity and reliability analysis were carried out. The analysis of the validity of this study includes content validity and item validity. Analysis of content validity through appearance validity and logical validity in testing using expert judgment. While the item validity analysis was carried out by statistical analysis using the Pearson Product Moment formula. Meanwhile, reliability testing was carried out with internal consistency using the Alpha Cronbach formula (Widiyanto, 2014; Yount, 1999). The Christian religion education instrument in the family was developed based on studies from Harianto GP (2012), Gulo (2017), Tampenawas, Ngala, \& Taliwuna (2020), Kristianto (2016), Tari \& Tafonao (2019), which were measured by four indicators, namely: 1) Parental Role Models, 2) Building Family Devotions or Family Altars, 3) Giving Repeated Advice Based on Christian Faith and 4) Educating Children by Sharing God's Word. Of the 20 items of the instrument through the analysis of the validity of the items obtained all valid with a reliability coefficient of 0.959

Parenting style for parents were developed by Dariyo (2011), Gunarsa (2004), dan Zen \& Novita (2018), which were measured by indicators including: 1) Authoritarian Parenting, 2) Permissive Parenting, and 3) Democratic Parenting. The results of the validity test of the 15 items of the parenting style instrument using item validity obtained all valid items with a reliability coefficient of 0.891 .

Meanwhile, the instrument for forming the character of Christ was developed based on studies from Setiawani and Tong (2010), Clinton and Leavenworth (2004), Arroan (2016), Hartono (2018), Ticoalu (2003), Situru (2020), Tampenawas, Ngala, and Taliwuna (2020), and Mutak (2016) as measured by the following indicators: 1) Love, 2) Integrity and Trustworthiness, 3 ) Obedience, 4) Generosity and Kindness, 5) Loyalty, 6) Patience, 7) Words and Gentleness, 8) Self-Control, and 9) Discipline and Responsibility. The results of the validity test of the Christ Character Formation instrument were obtained as many as 26 items were 
declared valid with a reliability coefficient of 0.939 . Analysis of research data was carried out using descriptive and inferential statistics, which included analysis of the average, minimum and maximum scores, standard deviation, simple correlation and regression analysis and correlation and multiple regression analysis.

\section{RESULTS AND DISCUSSION}

\section{Research Subject Demographics}

From the results of the analysis, a description of the research subjects is presented as follows:

\begin{tabular}{llcc}
\hline \multicolumn{2}{c}{$\begin{array}{c}\text { Participant } \\
\text { Demographics }\end{array}$} & Frequency & $\begin{array}{c}\text { Percentage } \\
(\%)\end{array}$ \\
\hline Gender & Male & 49 & 48.50 \\
\cline { 2 - 4 } & Female & 52 & 51.50 \\
\hline Age & $11-12$ years & 12 & 11.88 \\
\cline { 2 - 4 } & $13-14$ years & 35 & 34.65 \\
\cline { 2 - 4 } & $15-16$ years & 54 & 53.47 \\
\hline
\end{tabular}

Table 1. Research Subject Demographics
Based on the data in table 1 , from the number of research participants, there were 101 people, consisting of 49 people or $48.51 \%$ male and 52 people or $51.49 \%$ female. Thus, more female participants than male participants. Meanwhile, based on the age of the participants, it is known that from 101 people consisting of 12 people or $11.88 \%$ who have an age of 11-12 years, as many as 35 people or $34.65 \%$ who have an age of $13-14$ years and as many as 54 people or $53.47 \%$ who are $15-16$ years old. Thus, the number of respondents aged 1516 years is more than those aged 11-12 years and 13-14 years.

Descriptive analysis of each research variable obtained the results:

\begin{tabular}{lccccc}
\hline & $\mathrm{N}$ & Minimum & Maximum & Mean & Std. Deviation \\
\hline Christian religious education in the family & 101 & 58 & 100 & 85,53 & 10,876 \\
\hline Parenting style & 101 & 31 & 68 & 45,47 & 7,452 \\
\hline Character formation & 101 & 77 & 130 & 102,35 & 11,815 \\
\hline
\end{tabular}

Table 2. Data Description

Table 2 shows that the participants who have a score on the average cluster are 27 people or $26.73 \%$ for the Christian Religious Education in the Family variable. Participants who have scored in the cluster below the average, namely 31 people or $30.69 \%$. Participants who have scored in the cluster above the average, 43 people or $42.57 \%$. Because the participants who scored in the average and above-average cluster were more, namely 70 people or $69.31 \%$, which means that Christian Religious Education in the Family has been carried out well.

Based on table 2 for the parenting style variable, it's shown that the participants who have an average score in the cluster are 27 people or $26.73 \%$. Participants who have scored in the cluster below the average, namely 49 people or $48.51 \%$. Meanwhile, participants who have scored in the cluster above the average, namely 25 people or $24.75 \%$. Therefore, more participants get scores in the average and above-average cluster, namely 52 people or $51.49 \%$ which means that the parenting style conducted by the parents is good.

Based on table 2 for the formation of Christ's character in adolescents, shows that participants who have a score on the average cluster are 25 people or $24.75 \%$. Participants who have scored in the cluster below the average, namely 30 people or $29.70 \%$. Participants who have scored in the cluster above the average, namely 46 people or $45.54 \%$. Because more participants get scores in the average and above-average clusters, namely 71 people or $70.30 \%$, which means that the formation of Christ's character in adolescents has been carried out well. 
Data Analysis Results

The results of data analysis using correlation analysis and simple regression as well as correlation and multiple regression obtained the following results:

\begin{tabular}{llllllll}
\hline Variable & $\mathrm{a}$ & $\mathrm{b}$ & $\mathrm{r}$ & $\mathrm{r}^{2}$ & $\mathrm{t}$ & $\mathrm{p}$-value & Conclusion \\
\hline $\begin{array}{l}\text { Christian Religious Education in the Family } \\
\rightarrow \text { Character Formation }\end{array}$ & 45,857 & 0,676 & 0,623 & 0,381 & 7,914 & 0,000 & Significant \\
\hline Parenting Style $\rightarrow$ Character Formation & 83,584 & 0,413 & 0,260 & 0,058 & 2,682 & 0,009 & Significant \\
\hline
\end{tabular}

Table 3. Partial Analysis Results

The Influence of Christian Religious Education in the Family on Character Formation

The results of the analysis in table 3 show that the correlation coefficient between Christian Religious Education in the family on the formation of Christ's character in adolescents is 0.623 with a t coefficient of 7.914 with a $p$-value of 0.000 which means significant. These results indicate that Christian religious education in the Family has a significant effect on the formation of Christ's character in adolescents. This result means that increasing the implementation of Christian religious education in a good family will have an impact on increasing the formation of Christ's character in adolescents. A significant regression equation was obtained, namely $\hat{\mathrm{Y}}=45.857+0.676 \mathrm{X}_{1}$ which means that if the average score of Christian religious education in the family increases by one unit through the improvement program, it will increase the average score of Christ's character formation by 0.676 at a constant 45.857 . While the magnitude of the coefficient of determination $\left(r_{y x 1}^{2}\right)$ of 0.381 means that Christian religious education in the family contributes to the formation of Christ's character in adolescents by $38.1 \%$.

\begin{tabular}{llllllllll}
\hline Variable & $\mathrm{a}$ & $\mathrm{b}_{1}$ & $\mathrm{~b}_{2}$ & $\mathrm{r}$ & $\mathrm{r}^{2}$ & $\mathrm{t}$ & $\mathrm{F}$ & $\mathrm{p}$-value & Conclusion \\
\hline Christian Religious & 36,875 & 0,647 & 0,252 & 0,642 & 0,400 & & 34.330 & 0,000 & Significant \\
Education in Family \& & & & & & & 7,574 & & 0,000 & Significant \\
Parenting Style & & & & & & 2,019 & & 0,046 & Significant \\
Simultaneously $\rightarrow$ & & & & & & & & & \\
Character Formation & & & & & & & & & \\
\hline
\end{tabular}

Table 4. Simultaneous Analysis Results

\section{Parenting Style's Influence on Character}

\section{Formation}

The results of the analysis in table 4 show that the correlation coefficient between parenting patterns and the formation of Christ's character in adolescents is 0.260 with a $t$ coefficient of 7.914 with a $p$-value of 0.000 which means significant. These results indicate that parenting has a significant influence on the formation of the character of Christ in adolescents. This means that increasing the implementation of parenting by the characteristics of the child, good and appropriate, will increase the formation of the character of Christ in adolescents for the better. A significant regression equation was obtained, namely $\hat{\mathrm{Y}}=83.584+0,413 \mathrm{X}_{2}$, which means that if the average score of parent's style of parenting increases by one unit through the improvement program, the average score of the formation of Christ's character in adolescents will increase by 0.413 at the constant 83,584 . While the magnitude of the coefficient of determination $\left(r_{y x 2}^{2}\right)$ of 0.058 means that parenting parents contribute to the formation of Christ's character in adolescents by $5.8 \%$. 


\section{The Influence of Christian Religious Education in the Family and Parenting Style of Parents Simultaneously on Character Formation}

Based on table 4, the multiple correlation coefficient is 0.642 and the $\mathrm{F}$ coefficient is 34.330 with a p-value of 0.000 which has a significant meaning. These results indicate that Christian religious education in the family and parenting styles have a significant effect on the formation of Christ's character in adolescents. The magnitude of the coefficient of determination $\left(R_{y .12}^{2}\right) 0.400$ means that $40 \%$ of the variance in the formation of Christ's character in adolescents can be explained by Christian religious education in the family and parenting styles together.

The influence of Christian religious education in the family and parenting patterns together on the formation of Christ's character is shown by the multiple regression equation $\hat{Y}=$ $36,875+0,647 X_{1}+0,252 X_{2}$. Based on the results of the analysis on the regression coefficients for each variable, the $t$ coefficients are 7.574 and 2.019 with $p$-value coefficients of 0.000 and 0.046 which means partially significant, it is concluded that Christian religious education in the family and parenting styles simultaneously have a significant effect on the formation of the character of Christ in adolescents. Thus, efforts to form the character of Christ in adolescents at the GKII Sector 1 can be carried out by increasing the intensity of the implementation of Christian religious education in the family and increasing the appropriate parenting style.

The results of this study indicate that there is a positive and significant influence of Christian religious education in the family on the formation of Christ's character in adolescents. This result is in line with Chafin (1978) that the family is a place to grow in spiritual life. The implementation of Christian religious education in the family, both through the family altar, advice, and the provision of education sourced from God's Word by parents, has an impact on the spiritual growth of children. This growth is marked by the formation of character in the child. These results are in line with the research of Justian, Fernando dan Widiyanto (2020) that parents play a role in Christian religious education in the family. The significant role of parents will form the character of Christ in adolescents.

Christian religious education in the family through the role of parents through example will have a significant impact on the formation of children's character. Through the example of parents, children see figures who can be role models, so that there is imitation and internalization, namely taking the values in their parents' lives to be applied in themselves. The example of parents as a form of Christian religious education in the family, of course, the example that comes from the values of the Christian faith will shape and influence the development of the child's personality, especially in this context the formation of the character of Christ in adolescents (Harianto GP, 2012).

The results of this study also show that there is a significant effect of parenting on the character formation of adolescents. This result is in line with Susanto (2015), that parenting is reflected in the behavior of parents in treating their children, which affects the formation of children's identity. Through parenting which is reflected in the interaction model in which parents treat their children appropriately, through guidance, guidance, advice, and discipline and protection that can provide a sense of security for children, it will form good characters in children. In line with Chrisiana (2005) the formation of children's character starts from the family environment. Through the application of appropriate parenting styles, specifically in the application of democratic parenting styles, children will develop an independent, responsible, and even more confident personality, have high initiative, and make them easy to get along with and develop themselves, so that it has an impact on the formation of their character (Zen \& Novita, 2018). Through the implementation of Christian religious education in the family and the application of the right parenting 
style, it will have an impact on the formation of the character of youth like Christ.

\section{CONCLUSION}

Based on the results of data analysis, the conclusions of this study are as follows: First, Christian religious education in the family has a significant effect on the formation of the character of Christ in adolescents. Increasing the implementation of Christian Religious Education in the family carried out by parents, both through the family altar, providing advice, and also life examples will have an impact on the formation of the character of Christ in adolescents for the better. Second, parenting has a significant effect on the formation of the character of Christ in adolescents. The application of parenting that is following the characteristics of children and is carried out democratically will have an impact on the formation of the character of Christ in adolescents who are getting better. Third, Christian religious education in the family and parenting styles have a significant effect on the formation of the character of Christ in adolescents. Efforts made in implementing Christian religious education in family and the application of appropriate, democratic, and appropriate parenting

\section{REFERENCES}

Ariyanto, M. D., Mahmud, A., \& Wijayanti, T. Y. (2012). Konsep Puasa dalam Agama Protestan. Suhuf, 24(1), 99-119.

Arroan, R. A. (2016). Analisis Ketaatan Kristus Berdasarkan Filipi 2:1-11 Dan Implementasinya Bagi Orang Percaya Masa Kini. Sekolah Tinggi Theologia Jaffray.

Bharathi, T. A., \& Sreedevi, P. (2016). A Study on the Self-Concept of Adolescents. International Journal of Science and Research, 5(10), 512-516.

Butler-Barnes, S. T., Martin, P. P., \& Boyd, D. T. (2017). African American Adolescents' Psychological Well-Being: The Impact of Parents' Religious Socialization on Adolescents' Religiosity. Race and Social styles will have an impact on increasing the character of Christ in adolescents.

The implementation of Christian religious education in the family should be significantly improved, namely through the family altar and by setting an example as a parent to their children both in words, attitudes, and spiritual examples in daily life. Parents should also not get tired of organizing a family altar in building a spiritual life for the family, including their children.

Parents should continue to remind, provide guidance and advice to their children based on the values of the Christian faith so that children grow in Christ. The Word of God becomes a source of teaching amid the family so that the character of Christ will be formed in their children. Parents in shaping the character of their children to be like Christ by setting an example in aspects of spiritual life, such as setting an example in loyalty, honesty, responsibility, and a personality that reflects Christ.

Parents in carrying out parenting to their children must be appropriate, in particular the application of democratic parenting where parents provide controlled freedom so that children grow and develop in responsibilities and good personalities.
Problems,
9(2),
$115-126$. https://doi.org/10.1007/s12552-017-9199-8

Chafin, K. (1978). Is There a Family in the House? Texas: World Wide Publication.

Chrisiana, W. (2005). Upaya Penerapan Pendidikan Karakter Bagi Mahasiswa (Studi Kasus Di Jurusan Teknik Industri UK Petra. Jurnal Teknik Industri, 7(1), 83-89. https://doi.org/10.9744/jti.7.1.pp.\%2083-90

Clinton, R., \& Leavenworth, P. (2004). Menuai dengan Baik. Jakarta: Metanoia.

Dariyo, A. (2011). Psikologi Perkembangan Anak Tiga Tahun Pertama. Bandung: PT. Refika Aditama.

Darmawan, A. I., \& Wardhaningsih, S. (2020). Peran Spiritual Berhubungan dengan Perilaku 
Sosial dan Seksual Remaja. Jurnal Keperawatan Jiwa, 8(1), 75. https://doi.org/10.26714/jkj.8.1.2020.75-82

GP, H. (2012). Pendidikan Agama Kristen dalam Alkitab dan Dunia Pendidikan Masa Kini. Yogyakarta: Penerbit Andi.

Gulo, S. (2017). Prinsip Pendidikan Agama Kristen Dalam Keluarga Bagi Keluarga Banua Niha Keriso Protestan (BNKP) Gunung Sitoli. Jurnal Global Edukasi, 3(3), 452-456.

Gunarsa, S. . D. (2017). Psikologi Remaja. Jakarta: Libri BPK Gunung Mulia.

Gunarsa, S. Y. D. (2004). Psikologi Perkembangan Anak dan Remaja. Jakarta: BPK Gunung Mulia.

Hartono, H. (2018). Membentuk Karakter Kristen Pada Anak Keluarga Kristen. KURIOS (Jurnal Teologi Dan Pendidikan Agama Kristen), 2(1), 62-69. https://doi.org/10.30995/kur.v2i1.22

Justian, S., Widiyanto, M. A., \& Fernando, A. (2020). Korelasi Pola Asuh Orangtua Kristiani dengan Kecerdasan Emosional Siswa. Aletheia: Jurnal Teologi Dan Pendidikan Kristen, 1(1), 63-73.

Kristianto, P. L. (2006). Prinsip dan Praktik Pendidikan Agma Kristen. Yogyakarta: Andi Offset.

Mutak, A. A. (2016). Disiplin Rohani sebagai Praktek Ibadah Pribadi. Jurnal Theologi Aletheia, 18(10), 1-24.

Putro, Z. K. (2017). Memahami ciri dan tugas perkembangan masa remaja. Jurnal Aplikasi Ilmu Ilmu Agama, Volume 17(No 1), 25-32.

Rahman, Fa. P. A. (2016). Pengaruh Pola Asuh Orang Tua terhadap Kenakalan Remaja. Jurnal Inovasi Pendidikan Dasar, 4(1), 2329.

Riati, I. K. (2016). Pengaruh Pola Asuh Orangtua Terhadap Karakter Anak Usia Dini. Infantia, $4(2), 8$.
Setiawani, M., \& Tong, S. (2010). Seni Membentuk Karakter Kristen. Surabaya: Momentum.

Situru, I. D. (2020). Implementasi Pemuridan Kontekstual Untuk Meningkatkan Nilai-Nilai Karakter Kristiani Di Kelas Anak Remaja Jemaat Ukka'. https://doi.org/10.31219/osf.io/a9wbg

Suhesty, A., Setiaji, A., Amalia, R., \& Wibisono, M. D. (2019). Seminar "Kenakalan Remaja, Pencegahan dan Penanggulangannya." JURNAL PLAKAT: Jurnal Pelayanan Kepada Masyarakat), 1(1), 71-78.

Susanto, A. (2015). Bimbingan \& Konseling di Taman Kanak-kanak. Jakarta: Prenadamedia.

Tafonao, E. T. T. (2019). Pendidikan Anak dalam Keluarga Berdasarkan Kolose 3:21. Jurnal Teologi Dan Pendidikan Agama Kristen, 5 No. 1 .

Tampenawas, A. R., Ngala, E., \& Taliwuna, M. (2020). Teladan Tuhan Yesus Menurut Injil Matius dan Implementasinya Bagi Guru Kristen Masa Kini. EDULEAD: Journal of Christian Education and Leadership, 1(2), 214-231.

https://doi.org/10.47530/edulead.v1i2.44

Ticoalu, B. M. N. (2003). Kemurahan Allah Kepada Kita. Veritaseritas, 4(1), 133-139.

Widiyanto, M. A. (2014). Statistika untuk Penelitian Bidang Teologi, Pendidikan Agama Kristen, dan Pelayanan Gereja. Bandung: Kalam Hidup.

Yount, W. R. (1999). Research Design and Statistical Analysis in Christian Ministry. Fort Worth: Southwestern Baptis Theological Seminary.

Zen, D. S., \& Novita, L. (2018). Hubungan Pola Asuh Orangtua dengan Dengan Kecerdasan Emosional. JPPGuseda | Jurnal Pendidikan \& Pengajaran Guru Sekolah Dasar, 1(01), 3945. https://doi.org/10.33751/jppguseda.v1i01.870 